\title{
INOVACIJŲ KOMANDOS KŪRYBINGUMO VEIKSNIAI
}

\author{
Irena Zabielavičienè \\ Vilniaus Gedimino technikos universitetas, Basanavičiaus g. 28, LT-10225 Vilnius, Lietuva \\ El.paštasi-z@zmail.lt
}

Iteikta 2011-12-15; priimta 2012-02-15

\begin{abstract}
Santrauka. Straipsnyje pateikiama kūrybingumo veiksnių samprata ir ịvairių autorių požiūris ị kūrybingumo veiksnių tyrimo kryptis. Nagrinejjama įmonių organizacinių veiksnių ir darbuotojų, dirbančių inovacijų komandose, asmeninių savybių ịtaka jų kūrybingumui. Teigiama, kad geresnis kūrybinio potencialo naudojimas šalies pramonès įmonių inovacijų komandose turètų būti siejamas su dvasingos organizacinès elgsenos principụ ígyvendinimu praktikoje. Atskleidžiama, kuo skiriasi dvasingos organizacijos nuo nedvasingų, nagrinejjami organizacinès elgsenos dvasingumo veiksniai. Straipsnio autore išskiria tris pagrindinius inovacijų komandos nario, kaip asmenybès, kūrybingumo veiksnius: atvirumą, suvokimą ir idejiš̌kumą. Pateiktos atvirumo, suvokimo ir idejjiškumo sampratos, šių veiksnių ịtakos darbuotojo, dirbančio inovacijų komandoje, kūrybingumui analizės rezultatai. Darbuotojų asmeninių savybių įtaka kūrybingumui nagrinèjama kartu ịvertinant jų moralinès raidos lygị. Pateiktas darbuotojų moralinès raidos lygio klasifikavimo, išskiriant keturias jo stadijas, loginis pagrindimas. Taikant ekonometrinius metodus nustatyta darbuotojo moralinès raidos lygio įtaka kūrybingumo veiksniams. Tyrimo rezultatai parodè, kad didžiausią įtaką kūrybingumui turi darbuotojo idejiškumas, atspindintis tobulumo siekį. Reikšmingą ịtaką turi ir atvirumas, atspindintis asmenybès gebejimą kvestionuoti susiformavusias pažiūras. Suvokimas, atspindintis asmenybės pažinimo siekį, yra mažiausiai reikšmingas kūrybingumo veiksnys. Darbuotojo moralinès raidos lygio įtaka kūrybingumo veiksniams nustatyta taikant ekonometrinius metodus. Atliktas tyrimas parodė, kad darbuotojo, dirbančio inovacijų komandoje, moralinès raidos lygis turi ịtakos jo atvirumui, atspindinčiam gebejjimą kvestionuoti savo pažiūras, ir idejjiškumui, atspindinčiam tobulumo siekị. Darbuotojo suvokimas, atspindintis pažinimo siekị, nekoreliavo su jo moralinès raidos stadija. Darbuotojo, dirbančio inovacijų komandoje, kaip asmenybè, kūrybingumui tirti siūlomas modelis, jungiantis šiuos veiksnius: idejiš̌kumą ir atvirumą, kurie priklauso nuo jo moralinès raidos lygio, bei suvokimą. Žinant darbuotojų moralinès raidos lygio charakteristikas ir jų itaką tobulumo siekiui bei gebejimui kvestionuoti susiformavusias pažiūras, galima tikslingiau formuoti inovacijų komandas. Natūralu, kad komandoje susidaro įvairių lygių mišinys. Svarbu, kokio lygio yra dauguma ir kokị statusą ir vaidmenị komandoje užims aukštesnès moralinės raidos lygio nariai. Nuo to priklauso ne tik kokiais kriterijais remsis komandos nariai, priimdami sprendimus profesinės kompetencijos srityje, bet ir kaip bendraus, kokios susiformuos normos.
\end{abstract}

Reikšminiai žodžiai: inovacijų komanda, kūrybingumas, suvokimas, atvirumas, idejiiškumas, moralinė raida, dvasingos organizacijos principai.

\section{THE CREATIVITY FACTORS OF INNOVATION TEAM}

\author{
Irena Zabielavičienè
}

\author{
Vilnius Gediminas Technical University, Basanavičiaus g. 28, LT-10225 Vilnius, Lithuania \\ E-mail: i-z@zmail.lt
}

Received 15 December 2011; accepted 15 February 2012

\begin{abstract}
The article presents the concept of creativity factors and the point of view on the directions of the analysis of creativity factors by different authors. It investigates the impact on the creativity of firm organizational factors and personal characteristics of the employees working in innovation teams. The article asserts that the more efficient utilization of the creative potential in
\end{abstract}


the innovation teams of the Lithuanian manufacturing companies should be related to the implementation of spiritual organizational behavior principles in practice. It reveals what differentiates spiritual organizations from non-spiritual ones. The factors of spirituality of the organizational behavior are analyzed. The author of the article identifies three main characteristics of the innovation team members: openness, perception, high normal quality degree. The present study defines openness, perception, high moral quality degree, and presents the results of the analysis of the above factors on the creativity of an employee working in the innovation team. The impact of the employees' moral development consists of four stages. The article determines the effect of the employees' moral development level on the creativity factors using econometric methods. This analysis reveals that the high moral quality degree of an employee, which is related to his/her aspiration of perfection, has the largest impact on his creativity. The effect of openness, which relates to the ability of an individual to question the accepted views, has a substantial effect as well. Perception, which is related to the individual's aspiration of knowledge, is the least important factor of creativity. Econometric methods are used to determine the effect of the employee's moral development level on creativity factors. The analysis based on econometrics shows that the level of the moral development of an employee working in an innovation team has an impact on his/her openness, which reflects his/her ability to question their own views, and on his/her high moral quality degree reflecting his/her aspiration for perfection. The employee's perception reflecting his/her aspiration for knowledge is not correlated with his/her moral development level. The article suggests a model of the analysis of the creativity of employees' working in the innovation team. This model incorporates the following factors: high moral quality degree and openness, which depend on their moral development and perception. Knowing the characteristics of the employees' moral development level and their impact on the aspiration for perfection and ability to question accepted beliefs helps to form better innovation teams. It is normal for a team to have a blend of different levels. It is most important what the level of the majority is and what status and role in the team the members with a higher moral development level have. This does not only determine the criteria that team members will use to make decisions in their areas of professional competence, but also set the manner of co-operation and formulate the norms.

Keywords: innovation team, creativity, perception, openness, high moral quality degree, moral development, principles of a spiritual organization.

JEL Classification: O31.

\section{Itvadas}

Komandinis darbas inovacijų sferoje yra specifinis. Jis reikalauja didesnio komandos kūrybinio potencialo. Todèl, sudarant inovacijų komandas, reikia vadovautis mokslinių tyrimų teiginiais, sudarančiais galimybes preliminariai numatyti komandos narių kūrybingumą. Vadovavimas tokioms komandoms tampa sudètingesnis. Reikia sudaryti sąlygas atskleisti ir ugdyti komandos narių kūrybinius gebejjimus. Kūrybingos asmenybès yra jautresnès organizacijos psichologiniam klimatui ir vidinès kūrybingumo motyvacijos dirgikliams. Komandinio darbo specifika inovacijų sferoje mažai nagrinèta. Leidiniuose, skirtuose inovacijų tematikai, nagrinëjami tik bendrieji komandinio darbo principai. Tai reiškia, kad tikslinga plètoti šiuo metu teoriškai mažai nagrinëjamus veiksnius, turinčius ịtakos inovacijų komandos kūrybinio potencialo naudojimui. Jų rezultatai turètų sudaryti sąlygas metodiškam inovacijų komandos formavimo ir valdymo tobulinimui.

Tyrimo objektas - inovacijų komandos kūrybingumo veiksniai.

Problema. Tyrimai rodo, kad įmonėse mažai gilinamasi ¡̇ inovacijų komandos formavimosi procesą. Apsiribojama darbuotojų atranka vadovaujantis profesinès kompetencijos poreikiais. Nežinoma, kiek darbuotojų suvokimas, atvirumas ir idejjiškumas, atspindintys pažinimo siekị, atvirumą naujovèms ir gebėjimą kvestionuoti susiformavusias pažiūras bei tobulumo siekị, yra svarbūs inovacijų komandos kūrybingumui. Nežinoma, kaip minètos savybès susijusios su moralinès komandos nario raidos lygiu, atspindinčiu jo vertybinę orientaciją ir stiprybę ginti savo vertybes.
Reikalinga informacija ir apie inovacijų komandos vidinès motyvacijos dirgiklius.

Tyrimų tikslas. Pagrindinis tyrimų tikslas - metodiškai išnagrinèti inovacijų komandoje vykstančius reiškinius ir nustatyti veiksnius, kurie turi ịtakos jos narių kūrybingumui.

Tyrimas atliktas remiantis bendraisiais mokslinio tyrimo metodais: sistemine analize, logine analize ir anketinès apklausos duomenų regresine analize.

\section{Kūrybingumo veiksnių samprata}

Tatarkiewicz (2007) pabrěžia, kad šiandien kyla kūrybos garbinimo banga. Kūryba vertinama mažiausiai dèl dviejų priežasčių. Taip yra todèl, kad, pateikdama naujus daiktus, ji praplečia mūsų gyvenimo akiratị, taip pat todèl, kad yra žmogaus intelekto galios ir nepriklausomybès išraiška. Daugelis teoretikų laikosi požiūrio, kad kūrybingumas yra sudètingas reiškinys, kurị lemia ịvairių komponentų derinys. Literatūroje pateikiami ịvairūs kūrybingumo modeliai, jungiatys ịvairius komponentus. Plačiai paplitęs Urban (1990) modelis, jungiantis šešis kūrybingumo komponentus. Tai: specialios žinios, gebẻjimai ir igūdžiai; divergentinis mąstymas; bendros žinios; tolerancija neapibrežtumui (dviprasmybei); motyvacija; gebejjimas atlikti užduotị.

Kūrybingumas siejamas su asmenybės savęs aktualizavimo poreikiu, originalumu, savo gyvenimo misijos suvokimu ir vidine motyvacija. Runco (2004) teigia, kad kūrybingumas yra ịvairių savybių kompleksas: originalumas, lankstumas, veiklumas, gebejjimas spręsti problemas ir priimti iššūkius, lemti pokyčius tiek technologijos, tiek kul- 
tūros srityse. Rogersas (2005) kūrybingumą laikè bendražmogiška žmogaus savybe. Autorius teigia, kad pagrindinis veiksnys kūrybingumui atsiskleisti yra asmenybès poreikis aktualizuoti save, išskleisti savo potencialias galimybes ir patirti pasitenkinimą kuriant. Autorius nurodo šias vidines sąlygas, kurių reikia kūrybai:

- atvirumas patirčiai: ekstensionalumas;

- vidinè vertinimo kryptis;

- gebejjimas neịprastai derinti sąvokas ar gaunamos informacijos elementus.

Prie išorinių kūrybingumo atsiskleidimo sąlygų autorius priskiria psichologinę laisvę ir psichologinị saugumą. Rogerso nuomone, psichologinis saugumas sukuriamas trimis būdais:

- Visiškai pripažịstant asmens vertingumą be jokių išankstinių sąlygų ir reikalavimų.

- Nevertinant kito pagal savo susikurtą vertybių sistemą.

- Empatiškai priimant kitą asmeni.

Rogerso teiginiai, atskleidžiantys esminius veiksnius ir sąlygas kūrybingumui atsiskleisti, ypač aktualūs šiandien analizuojant potencialias inovacijų komandų galimybes. Šių teiginių taikymas praktikoje padètų vadovams suvokti rekonceptualizacijos svarbą įmonès plètrai ir iš esmès keistụ santykius tarp vadovo ir pavaldinių. Šiuo metu daugumoje ịmonių ị darbuotojų kūrybingumą žiūrima tik kaip i galimybę padidinti įmonès pajamas bei pelną ir visiškai nekreipiama dèmesio ị darbuotojų intelekto galios ir nepriklausomybės išraišką. Imonèse nededama jokių pastangu pripažinti darbuotojo vertingumą be jokių išankstinių sąlygų ir reikalavimų, t. y. priimti ji tokį, koks yra. Darbuotojas gali jaustis saugus tik tuomet, kai suvokia, kad yra vertinamas toks, koks yra, kai vadovai, pažindami potencialias jo asmenybès savybes, tiki jo galimybėmis. Tik tuomet, kai vadovas sugeba įsijausti ị tai, ką darbuotojas mąsto, jaučia, suvokia, šis gali jaustis saugiai ir išreikšti savo nuomonę. Jam nereikia jaudintis dèl to, ką pagalvos kiti. Tik suprantant ir pripažistant asmeninę žmogaus laisvę veikti vadovaujantis savo pažiūromis, galima prasmingai kalbèti apie kūrybinio potencialo naudojimą įmonèse ir jų suformuotose inovacijų komandose.

Simontono (2000) manymu, populiarūs du kūrybingumo modeliai. Vienas jų apima kūrybos proceso, produkto ir asmenybès tyrinejimus. Šiam modeliui priskirtume ir Rogerso modeli. Kitas modelis, pasak Simontono, yra „ekonominis - komercinis“. Autorius teigia, kad, vadovaujantis šiuo modeliu, nesiremiama jokia teorija, tik skatinama greitai ištyrinèti kūrybingumo apraiškas ir investuoti $\dot{i}$ "kūrybingumą" kaip ị brangią prekę. Pramonès įmonių inžinerinio personalo, dirbančio inovacijų komandose, apklausa parodè, kad šio modelio principu ir vadovaujamasi šalies pramonės įmonių praktikoje.

\section{Inovacijų komandos kūrybingumo veiksniai}

Naujos psichologijos krypties - egzistencinès analizès pradininkas Frankl (2007) išskiria tris vertybių kategorijas: kūrybines, išgyvenimo ir nuostatos. Kūrybines vertybes galima igyvendinti aktyvia veikla. Išgyvenimo vertybès igyvendinamos ką nors išgyvenant. Straipsnio autorès nuomone, išgyvenimas inovacijų komandos veikloje pasireiškia kaip savęs realizavimas ką nors kuriant. Frankl (2007) teigia, kad žmogus realizuoja save tik tiek, kiek igyvendina prasmę: savęs realizavimas įvyksta savaime kaip prasmės igyvendinimo pasekmé, o ne tikslas. Autorius pabrèžia, kad prasmè visada turi lenkti būtị, ir tik tokiu atveju išlieka pačios prasmès, kaip būties novatoriaus, prasmè. Nuostatos vertybių igyvendinimas priklauso nuo žmogaus santykio su jo gyvenimo apribojimais. Komandinio darbo specifika inovacijų sferoje turètų būti siejama su kūrybinių ir nuostatų vertybių derinimu. Imonè teikia inovacijų komandai galimybę igyvendinti ir vienos, ir kitos kategorijos vertybes. Dažnai ji reikalauja iš komandos igyvendinti kūrybines vertybes ir verčia atsigręžti i nuostatos vertybes, sukeldama kūrybinio darbo dirgiklius ir ribojimus.

Vidinę komandos narių kūrybingumo motyvaciją (troškimo kažką daryti, nes tai įdomu ir teikia pasitenkinimą, vilioja asmeniškai) gali veikti neigiamai psichologinè rutina, kurią sukelia jos ryšiai su organizacija (pavyzdžiui, jai reguliuojant kūrybinị darbą). Kūrybingumo vidinei motyvacijai gali kliudyti šios priežastys:

1. Suvaržytas pasirinkimas. Šiuo atveju komandai nustatomos ribos, kurių ji negali peržengti.

2. Priežiūra, kurią vykdo administracija, prižiūrèdama ir kontroliuodama komandos darbą.

3. Konkurencija. Administracija skatina lenktyniavimą tarp komandų ar organizacijos padalinių. Lenktyniaujant problemos sprendžiamos paviršutiniškai ir mažai dèmesio skiriama esminiams klausimams.

4. Laukiamas ịvertinimas ir akcentuojamas atlygis. Specialistai gali siūlyti ir bandyti naujas idejas tik tada, kai yra saugūs dèl darbo vietos ir atlygio. Jų pastangos turètų būti atlygintos pastoviu darbo užmokesčiu net ir tuo atveju, jei darbas nebuvo rezultatyvus.

Inovacinėje veikloje dažniausiai reikalingos ịvairių sričių žinios ir patirtis. Komandos darbuotojai turi būti ne tik kompetentingi savo srityje, bet ir privalo turèti pakankamą kieki žinių iš kitų sričių, kad galètų rasti sąlyčio taškus kūrybos procese. Tai reiškia, kad profesinès kompetencijos srityje reikalingas komandos narių suderinamumas.

Ne mažiau svarbus ir komandos narių asmeninių savybių suderinamumas. Inovacijų sferoje dirbančios komandos išskirtinumą lemia tai, kad jos narių suderinamumą apsunkina tokios kūrèjams būdingos savybès: noras siekti nepriklausomybès, didelis pasitikejimas savimi, noras imtis rizikos, tolerancija dviprasmybèms. Todèl aktualesnis tam- 
pa komandos narių psichologinis suderinamumas - atitikimas pagal analogišką situacijų suvokimą, vertinimą, adekvačias emocijas, jausmus, panašią vaizduotę ir mąstymą. Sudarant komandą, reikètų atkreipti dèmesį ir ị socialinį bei psichologinį darbuotojų suderinamumą, t. y. atitikimą pagal pasaulěžiūrą, įsitikinimus, vertybinę orientaciją.

Ryšys tarp komandos darnos ir produktyvumo priklauso nuo joje susiformavusių normų. Darna, kai vyrauja normos, skatinančios rezultatyviai dirbti, komandos produktyvumą veikia teigiamai. Kai komandoje veikia normos, silpnai orientuotos ị darbo rezultatus ir pastangas, susidaro socialinio dykinėjimo sąlygos. Vieni darbuotojai nesistengia ar nesugeba gerai dirbti, o kiti, kurị laiką nuoširdžiai dirbę, pervertina savo pastangų tikslingumą ir atkuria socialinị teisingumą, sumažindami savo indèlį. Inžinerinio personalo, dirbančio pramonès itmonių inovacijų komandose, apklausa parodè, kad socialinio dykinèjimo požymiai pasireškia gana dažnai. Todèl daugelis komandų nepasiekia brandos stadijos. Kuo darnesne komanda, tuo sunkiau keisti joje susiformavusias normas. Galime daryti įtaką komandos normoms, jei lyderio savybèmis pasižyminčius, bet nekonstruktyvų požiūrị ị darbą ir pastangas turinčius narius keisime naujais, panašios kompentencijos darbuotojais. Inžinerinio personalo, dirbančio pramonès i̇monių inovacijų komandose, verbalinès apklausos rezultatai rodo, kad pasiekti suderinamumą profesinès kompetencijos srityje yra lengviau, negu pasiekti darnos komandoje, kurioje normos būtų stipriai orientuotos į darbo rezultatus ir pastangas.

Darbuotojas, siekiantis profesinio tobulumo, nori komforto sąlygų. Jų negalima sukurti tik materialiniais ištekliais. Intelektualiam darbuotojui neužtenka tik geru daiktinių sąlygų. Jam būtinas teigiamas psichologinis klimatas. Psichologinis klimatas yra emocinis nusiteikimas, vyraujantis komandoje. Tai psichinè komandos būsena, kuri integruotai atspindi jos veiklos sąlygas. Ji aprèpia kognityvinį ir emocinį komponentus. Kognityvinis komponentas lemia tai, kad psichologinį klimatą veikia ne tik santykiai komandoje, jis turi įtakos komandos narių elgesiui, o kartu ir santykiams.

Teigiamą psichologinị klimatą lengviau palaikyti, kai komandos nariai turi empatijos - sugebèjimo „atsistoti i kito vietą ir žiūrèti jo akimis“ - igūdžių. Tai lengviau sekasi asmenims, turintiems didelę patirtị. Kai komandos nariai jaučia tai, ką išgyvena kolega, kitaip klostosi santykiai ir jų subjektyvus atspindys - psichologinis klimatas. Empatijos principas labai sèkmingai gali būti taikomas ir profesineje srityje. Tai vienas iš būdų sprendžiant sunkiausią inovacinès veiklos darbo problemą - nenorą atsisakyti tradicinio mąstymo.

Socialinès ir psichologinès refleksijos igūdžiai taip pat reikalingi bendraujant su kitais komandos nariais. Tai supratimas, kaip kitas suvokia tave. Tai gebėjimas „pasižiū- rèti ị save iš šalies“. Pasižiūrèjus ị savo elgesị, kalbą, teiginius „iš šalies“, suprantama kitų reakcija dèl kai kurių poelgių, nustatomas neatitikimas tarp kalbos turinio ir pateikimo formos, padaromos išvados, ar teiginiai pateikiami įtaigiai ir t. t. Kai inovacijų komandą sudaro įvairių sričių specialistai, neturintys refleksijos igūdžių, daug laiko sugaištama norint suprasti problemos visumą ir rasti bendrus sąlyčio taškus integruojant ịvairių sričių žinias konkretiems uždaviniams spręsti.

Komandos narius motyvuoja ne tik tikèjimas, kad pastangos bus susietos su atlygiu, bet ir suvokimas, kiek teisingas indelio ir atlygio santykis. Savo ir kitų komandos narių indèlio ir atlygio santykio įvertinimas priklauso nuo vertinančio asmens suvokimo. Tarp komandos narių gali būti suvokimo iškraipymų. Pavyzdžiui, jei darbuotojas pakankamai nę̇vertina gebėjimų, reikalingų kūrybiniam darbui, ir neatsižvelgia ị jų itaką komandos darbo rezultatams, jam gali atrodyti, kad kitų komandos narių indèlio ir atlygio santykis yra mažesnis. Todèl vadovai turi suprasti, jog svarbu ne tik objektyviai ịvertinti komandos nariu darbą, bet ir tai, kad jie tai teisingai suvoktų. Jei komandos narys mano, kad jo indèlio ir atlygio santykis yra mažesnis negu kitų narių, jis traktuoja tai kaip neteisybę ir dažniausiai jaučia vidinę itampą, kuri motyvuoja jị keisti situaciją, kad būtų grąžintas teisingumas. Kasiulis ir Barvydienè (2005) teigia, kad darbuotojas, pajutęs neteisybę, gali pradèti gintis ir psichologinèmis priemonèmis, mègindamas iškreiptai suvokti savo indèlį ir taip sumažinti vidinę itampą. Toks indèlio ir atlygio pusiausvyros atkūrimo būdas darbuotojo mintyse slegia jo psichiką, skatina nevisaverčio komandos nario jausmą.

Reikia aiškiai apibrèžti komandos materialinio skatinimo kriterijus ir jų laikytis. Taip komandos vadovas gali sumažinti nevienodo suvokimo pasekmes. Komandos vadovo tikslas - ne tik paaiškinti ar parodyti kelius, kaip darbuotojams pasiekti tikslus, bet ir motyvuoti darbuotojus, kad jie pakiltų aukščiau turimų asmeninių interesų.

Transformacinis vadovas motyvuoja padaryti daugiau, negu darbuotojai tikisi. Norint būti transformaciniu vadovu ir daryti įtaką inovacijų komandos darbui, reikia išnaudoti visą savo energiją ir ižžalgumą, kad būtų ikvèptas pavaldinių entuziazmas, pasitikejimas ir lojalumas. Teigiama (Robbins 2003), kad daugelis vadovų nesugeba pasikeisti, kad galètų vadovauti komandoms. Jie turi igyti tokių igūdžių: kantriai pasikeisti informacija; pasitikèti kitais; atsisakyti valdžios; žinoti, kada reikia įsikišti. Todèl labai svarbus tampa vadovo emocinio intelekto lygis.

Emocinis intelektas apibrèžiamas kaip nekognityvių igūdžių, gebèjimų ir kompetencijos rinkinys, darantis įtakąžmogaus gebejjimui susidoroti su aplinkos reikalavimais (Goleman 2007). Vadovas turi būti komandos problemų diagnozuotojas. Jis turi pastebèti kylančių komandos problemų požymius, nustatyti jų priežastis ir padèti jas spręsti. 
Tai gali būti problemos dèl komandos narių suderinamumo profesinès kompetencijos srityje. Tačiau daugiausia problemų kyla dèl komandos narių asmeninio suderinamumo. Komandai pereinant įvairias formavimosi stadijas, kyla jos narių tarpusavio priklausomybès, atsakomybès, atvirumo, pasitikejimo problemos. Efektyviai dirbantys vadovai jaučia, kada komandai reikalinga pilna ar iš dalies apribota laisvè ir kada reikalinga organizacijos pagalba. Kartais komandos plètra ịstringa ir reikia modifikuoti jos elgseną. Inovacijų komandos kūrybingumą veikia ne tik organizaciniai veiksniai, bet ir asmeninès jos narių savybès.

Inovacijų komandos nario kūrybingumui turi ịtakos jo suvokimas, atvirumas ir idejjiškumas (1 pav.). Suvokimas yra visų jutiminių ịspūdžių registracija ir apdorojimas, daikto, situacijos ar ịvykio visumos atspindejjimas sąmonèje. Šiuo būdu žmogus atpažịsta ir pažįsta ji supančią aplinką. Suvokimas yra esmine pažinimo proceso dalis, susijusi su mąstymu, atmintimi, dèmesiu, be to, suvokimą veikia pažinimo motyvai, emocijos, jam turi itakos suvokejo tikslai, todèl suvokimo procesai yra intencionalūs, jais išskiriamas informacinis situacijos turinys. Pagal ji žmogus gali palyginti suvokiamus objektus su savo atmintyje saugomais ankstesniais tų objektų vaizdais ir juos atpažinti. Suvokimas panašus į mąstymo procesą tuo, kad gali transformuoti vaizdą ir padaryti jị tinkamą sprendimui priimti. Tokie perkūrimai, dažnai nesąmoningi, gali padèti kūrybingai išspręsti kilusius uždavinius. Suvokimas padeda pažvelgti ị tą pačią problemą skirtingais kampais ir gali sužadinti naujus sprendimus ir nurodyti naujas veiklos kryptis.

Idejjiškumas - žmogaus būdo bruožas, rodantis atsidavimą kilnioms idejoms. Idejjiškumas glaudžiai susijęs su nuoširdžiu tikejimu savo siekių teisumu ir keičia žmogaus gyvenimą, iprasmina veiklą. Kilnios idejos yra ne kas kita, kaip samprata tobulumo, kurio dar nèra tikroveje, bet kurio siekiama. Idẻjos, prasiskverbusios ị gyvenimą, igyja didelę galią. Jos suteikia žmogui neišsenkamos energijos, padeda jam nugalèti, atrodo, nę̧veikiamus sunkumus. Kilnios idejjos neatsiejamos nuo gèrio, žmoniškumo ir teisingumo. Žmogaus beidejjiškumas dažnai iggyja neigiamų orientacijų, pavyzdžiui, skepticizmo, nihilizmo ar cinizmo. Toks individas paskęsta kasdienybëje, suprimityveja, nuskursta dvasiškai. Idejiškumas išreiškia žmonių nepasitenkinimą esama tikrove ir norą ją padaryti tobulesnę, t. y. siekimą idealo. Jis, nubrèždamas ateities perspektyvas, nurodo pagrindinį tikslą, dèl kurio verta kurti. Aiškus realybès vaizdas sugretinamas su vizija - kyla „kūrybinè įtampa“. Ji skiriasi nuo emocinès įtampos, kuri sukelia nerimą. Kasiulis ir Barvydienè (2005) teigia, kad mūsų vizija supaprastėja (suprimityvejja), jei šių ittampų neatskiriame. Tai sumažina emocinę ịtampą. Autorių nuomone, tokiu atveju tolesnę eigą sudaro kompromisai ir kelias į vidutinybę. Kūrybinga asmenybe naudojasi ta spraga tarp vizijos ir realybès, kad sukurtos energijos skatinama siektų pakitimų. Atlikta pramonès įmonių inžinerinio personalo, dirbančio inovacijų komandose, apklausa parodo apie vadovavimo stiliaus ittaką jų kūrybinio potencialo naudojimui. Tik 40,9\% apklaustųjų pažyméjo, kad vadovavimo stilius yra tinkamas siekiant panaudoti darbuotojų kūrybini potencialą. Iš apklausos duomenų susidaro vaizdas, kad inžinerinio personalo norą kurti ir siekti geresnių rezultatų riboja įmoneje susiformavę bejejgiškumo ir bevertiškumo jausmai. Tokie jausmai lemia ìvairias strategijas, sprendžiant konfliktą tarp dabarties ir norimos ateities. Kasiulis ir Barvydiené (2005) pažymi, kad tokiu atveju galimos minèto konflikto sprendimo strategijos yra šios: viena strategija „leidžia“ suardyti viziją, kita - kon-

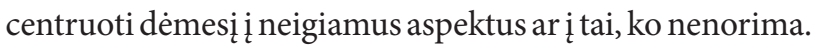
Trečioji strategija pasižymi stipria valia arba savęs drąsini$\mathrm{mu}$, ịveikiant visas galimas pasipriešinimo formas. Tačiau tai tinkama ne visuomet. Daugelyje įmonių specialistai vertinami pagal tai, kaip greitai ir tvirtai (nesvyruodami) jie

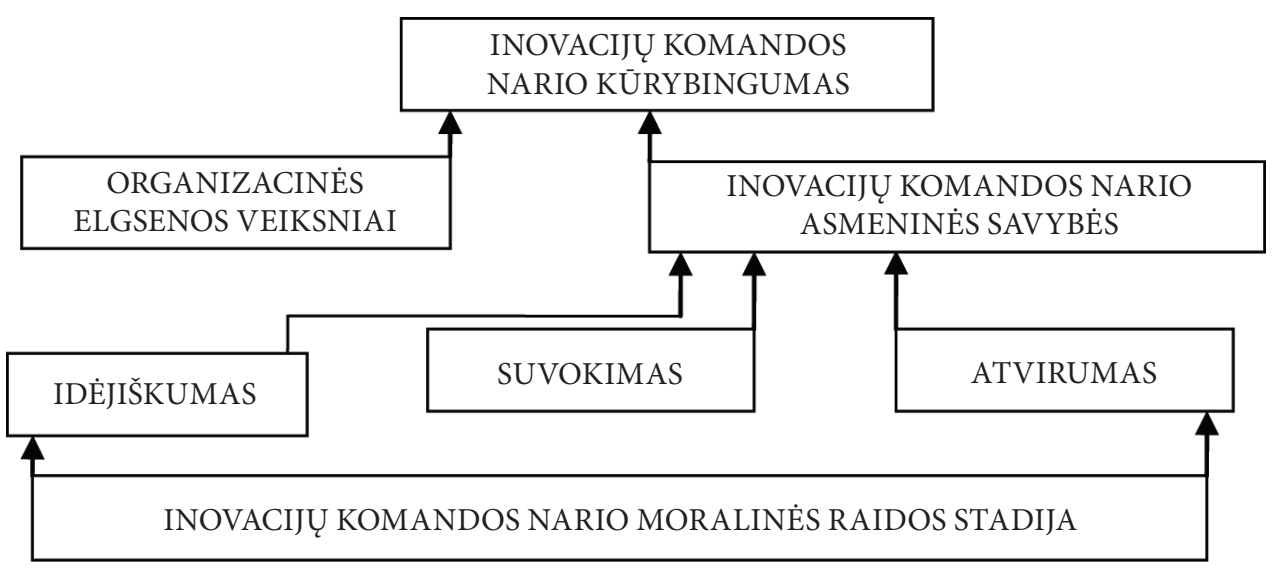

1 pav. Veiksnių, veikiančių inovacijų komandos nario kūrybingumą, tyrimo modelis

Fig.1. The model of factors influencing the creativity of a team member 
priima sprendimus. Tokiu atveju neapibrèžtumas, netikrumas neturi teisès egzistuoti, nes tai laikoma specialisto silpnumo požymiu. Iš jo laukiama ryžtingo sprendimo. Tačiau ryžtingas sprendimų priemimas, neatsižvelgiant ị sunkumus juos iggyvendinant, gali ir nepasiteisinti. Paprasčiausia strategija, ịveikiant struktūrinị konfliktą tarp dabarties ir norimos ateities, yra ịsipareigojimas sakyti tiesą. Tai reiškia ne „tiesos" kaip tokios, kaip absoliuto siekimą, o nepaliaujamą pasiryžimą neapgaudinèti savęs tuo, ką matome, ir drąsą mesti iššūkị savo mąstymo modeliams.

Atvirumas naujovèms pirmiausia reiškiasi kaip siekis kvestionuoti ịsitikinimus ir pažiūras savęs ieškojimo kelyje, kurị apibūdina nebesugrąžinama praeitis ir dar neapibrèžtos ir kylančios ateities galimybès. Šios galimybès leidžia ir verčia žmogų keisti esamas gyvenimo pažiūras, formuoti ir realizuoti naujas. Taigi atvirumas glaudžiai susijęs su nuoširdžiu noru keistis ir tikèjimu, kad tai lems geresnę ateiti. Pasitenkinimas esama tikrove ir nenoras pervertinti savąsias tiesas paverčia jas negyvomis dogmomis. Aklas ir besąlygiškas jų laikymasis veda prie neapykantos skirtingiems ịsitikinimams, proto sustabarejimo ir nekūrybingo mąstymo.

Pateikus apklausiamiesiems, dirbantiems inovacijų komandose idejiškumo, suvokimo ir atvirumo sampratą, jie idejiškumą interpretavo kaip siekị tobulumo, suvokimą - kaip siekị pažinimo, atvirumą - kaip gebèjimą keisti pažiūras. Darbuotojai vertino ne save, o komandos narius. Apklausos metu kūrybingumas $(y)$, atvirumas $\left(x_{1}\right)$ suvokimas $\left(x_{2}\right)$ ir idejiškumas $\left(x_{3}\right)$ buvo vertinami balais nuo 1 iki 5. Nustatyta darbuotojų, dirbančių inovacijų komandose, kūrybingumo priklausomybès nuo jų atvirumo, suvokimo ir idejiškumo aproksimantè:

$$
y=0,5012+0,3852 x_{1}+0,0998 x_{2}+0,7511 x_{3},
$$

čia $y$-darbuotojo kūrybingumas; $x_{1}$ - darbuotojo atvirumas; $x_{2}$-darbuotojo suvokimas; $x_{3}$-darbuotojo idèjiškumas.

Apklausos metu buvo renkami duomenys norint nustatyti, kaip susijusias komandos narių savybės: atvirumas, suvokimas ir idejjiškumas su jų moralinès raidos lygiu.

Ivairių darbuotojų i̇sipareigojimo įmonei lygis nèra vienodas. Todèl jų sprendimų priẻmimą ir elgesị ịmonèje nevienodai veikia baimès jausmas ir asmeniniai interesai. Literatūroje darbuotojo įsipareigojimas organizacijai siejamas su pasitenkinimu darbu (Meyer et al. 2002; Becker et al. 1996), geru organizaciniu icsitraukimu (Meyer et al. 2002), papildomos atsakomybés prisiemimu (Riketta 2005). Organizacinis įsipareigojimas kaip organizacijos funkcionalumo prielaida nagrinèjamas bandant išsiaiškinti ryšius, susaistančius individą su tam tikromis pareigomis tam tikroje organizacijoje (Kavaliauskienè 2009) ir formuojant pažinimo sistemą, padedančią suprasti tiek individų, tiek organizacijos elgseną (Vuuren et al. 2008). Petkevičiūtè ir
Kalnina (2004) teigia, kad organizacinis șsipareigojimas - tai asmens individualios identifikacijos ir ịsitraukimo ị tam tikrą organizaciją santykinè jèga, apibūdintina trimis veiksniais: stipriu tikèjimu organizacinèmis vertybèmis ir tikslais, pasiryžimu dèti daug pastangų organizacijos labui ir stipriu noru būti organizacijoje. İsipareigojimą motyvuojančiu veiksnių tyrimuose (Elizur, Koslowsky 2001; Van Vianen 2000) ypač akcentuojama vertybių svarba. Nagrinëjamas darbuotojų inovatyvumas kaip vertybe ir teigiama, kad jis įvairiose įmonèse užima skirtingą hierarchinị lygị vertybių sistemoje (Maceika et al. 2007).

Atsižvelgdami ị darbuotojų ísipareigojimo organizacijai lygmeni, galime ne tik sistemingai nagrinèti jų suvokimą, atvirumą, idejiškumą, bet ir geriau suprasti, kodèl du vienodai išsilavinę žmonès, turintys tą pačią informaciją, gali remtis skirtingais kriterijais vertindami galimų sprendimų alternatyvas. Iৃvairūs žmonès savo sprendimams taiko skirtingus etinius standartus. Tai priklauso nuo jų moralinès raidos lygio. Literatūroje (Robbins 2003) darbuotojo moralinės raidos lygis analizuojamas išskiriant tris jo lygmenis: pieškonvencinį, konvencinị ir principų. Kiekviename lygmenyje išskiriama po dvi stadijas. Remiantis Robbins (2003) pateikta analizės logika ir praktikos stebejjimų rezultatais, darbuotojų moralinès raidos lygị straipsnio autorè klasifikavo išskirdama keturias jo stadijas.

Pirmajai stadijai priskirti darbuotojai, kurių sprendimus riboja baimès jausmas. Baimé silpnina žmogaus valią, gniuždo iniciatyvą, veiklumą ir kūrybiškumą. Dažniausiai baimė pakerta žmogaus kūrybines galias: dèl savo reputacijos; būti nesuprastam ir pašieptam; kad naujos idejos bus iškraipytos ar nusavintos; kad nepakankama kompetencija; dèl atlygio. Baimès apimtas žmogus patiria, kad jis nèra saugus, ir kūrybinè laisvè virsta jam nebepakeliama našta.

Antrajai stadijai priskirti darbuotojai, kurių sprendimus riboja asmeniniai interesai. Tokie darbuotojai yra drąsesni kelti naujas idejjas, bet jų dèmesys sutelktas ị save. Jie daugiau linkę konkuruoti ir stengiasi tapti „pačiais svarbiausiais“. Darbuose, kur už laimèjimą dosniai atlyginama, jie yra produktyvūs. Tačiau jei nèra absoliučių veiklos vertinimo standartų ir ị asmeninius interesus orientuotas darbuotojas nejaučia tiesioginès motyvacijos, jo pastangos nuoširdžiai dirbti yra ribotos.

Trečiajai stadijai priskirti darbuotojai, kurie, priimdami sprendimus, laikosi ịsipareigojimų organizacijai principo. Tokie darbuotojai, priimdami sprendimus ir vykdydami prisiimtus įsipareigojimus, laikosi nustatytos organizacijoje tvarkos.

Ketvirtos stadijos darbuotojų pažinimas yra sudètingesnis. Žmogus, kuris didelę reikšmę teikia vaizduotei, nepriklausomybei ir laisvei, tikriausiai nepritaps įmonejje, siekiančioje, kad jos darbuotojai laikytųsi formalių taisykliụ bei normų. Vadovai bus labiau linkę pripažinti, teigiamai vertinti ir skirti paskatinimus darbuotojams, kurie „pritam- 
pa“. Organizacijos, remiančios dvasingą kultūrą, pripažìsta, kad žmonès savo darbe ieško prasmès. Dvasingumo tikslas pagalba darbuotojams rasti savo darbinio gyvenimo prasmę. Dvasingumas darbe apibrèžiamas (Ashmos, Duchon 2000) kaip pripažinimas, kad žmonès turi vidini gyvenimą, kuris skatina prasmingą darbą, vykstantį bendruomenės kontekste, ir kurị šis prasmingas darbas savo ruožtu ugdo. Tyrimų metu (McCormik 1994; Mirvis 1997; Robbins 2003) buvo nustatyta, kad dvasingumas organizacijoje teigiamai susijęs su kūrybingumu. Literatūroje nagrinèjama, kas išskiria dvasingas organizacijas nuo nedvasingų. Wagner-Marsh ir Conley (1999) akcentuoja šiuos bruožus, būdingus dvasingoms organizacijoms: stiprų tikslo pojūtị, dèmesį darbuotojų asmeniniam tobulejimui, pasitikejjimą ir atvirumą, igaliojimų suteikimą darbuotojams, darbuotojų saviraiškos toleravimą. Dvasingos organizacijos kuria savo kultūrą remdamosi prasmingu tikslu. Nors pelnas organizacijos vadovams ir investuotojams yra svarbus, bet jis negali būti reikšmingiausia organizacijos vertybe. JAV konsultacinès firmos atliktas tyrimas (Conlin 1999) parode, kad organizacijos dvasingumas ir pelnas gali labai puikiai derèti. Kompanijos, įdiegusios dvasingumu pagrịstus metodus, pagerino produktyvumą ir labai sumažino darbuotojų kaitą. Dvasingos organizacijos ne tik duoda žmogui darbą, bet ir pripažįsta jo vertę. Jos stengiasi sukurti tokius santykius ir psichologinị klimatą darbe, kuris skatintų žmogų nuolat mokytis ir tobulèti.

Būtina, nors ir nepakankama sąlyga, padaryti organizacijos valdymą dvasingą, yra pasitikèjimo, sąžiningumo ir atvirumo principu igyvendinimas praktikoje. Jeigu darbuotojai matys, kad vadovai tik deklaruoja šias vertybes, o jų nesilaiko, santykiai organizacijoje nebus dvasingi. Jei norime, kad šios vertybès veiktų organizacijos elgesị visose jos veiklos sferose, reikia aiškiai suvokti jų svarbą organizacijos vertybių hierarchijoje ir būti pasiryžusiems jas apginti ir palaikyti įvairiomis priemonemis. Vertybinès orientacijos keitimas reikalauja daug pastangų. Neužtenka vertybę propaguoti. Ji turi atsiskleisti per darbuotojų elgesį konkrečiais veiksmais. Vertybių negalima dirbtinai sureikšminti ir piršti darbuotojams. Išorinis, formalus vertybiu priemimas, giliau jų neịsisąmoninus, iš esmès nekeičia padèties ir gali būti tik konkrečių poreikių ar reikalavimų tenkinimo išraiška. Vertybiu „isitvirtinimas“ organizacijoje - tai procesas, apimantis tam tikrus etapus. Vertybès turi pereiti pristatymo stadiją. Šioje stadijoje ypač svarbus vadovų ǐžvalgumas. Tik visapusiškai įvertinus situaciją organizacijos padaliniuose ir vyraujančią vertybinę orientaciją, galima parinkti tinkamą pasitikejjimo, atvirumo ir sąžiningumo vertybių pristatymo būdą priimtina darbuotojams forma. Vertybių pristatymo stadijoje atvirumas, sąžiningumas ir pasitikèjimas turètų būti siejami ne su darbo rezultatais, o su darbuotojo požiūrio į darbą pokyčiais, jo potencialių galimybių atsiskleidimu. Šių vertybių įtaka darbo rezultatams ryškejja vèlesnèse jų gyvavimo ciklo etapuose - issigyvenimo ir klestejjimo stadijose. Atviri, sąžiningi ir pasitikintys darbuotojai gali prisiimti ir didesnius igaliojimus.

Organizacija tampa dvasingesné, jei vadovavimas daugiau remiasi ne sukurtomis taisyklemis ir procedūromis, o politika, kai darbuotojas pats gali ịvertinti ịvairias sprendimo alternatyvas ir, remdamasis organizacijos nuostatomis, ji priimti. Dvasinga organizacija išsiskiria iš kitų ir tuo, kad toleruoja darbuotojų saviraišką. Ji leidžia darbuotojams atvirai išreikšti savo nuomonę, nuotaikas ir jausmus, nebijant dèl pasekmių. Išugdyti organizacijoje tokį darbuotojų laisvumą, kad jie atvirai reikštų savo nuomonę, nèra lengva. Žmonès mieliau norètų pateikti ne tikruosius, o socialiai priimtinus vertinimus, pažiūras. Todèl kartais darbuotojai pasako ne tai, ką galvoja, o pateikia nuomonę, kurios privalètų laikytis, kuriai pritars vadovai ir kurią palaikys bendradarbiai. Todèl būtina stebėti darbuotojų veiksmus, ypač ištikus krizinei situacijai. Veikla tokiomis sąlygomis yra patikimiausias informacijos šaltinis, galimybė palyginti kalbas ir darbus (Kasiulis, Barvydienė 2005). Vadovai turètų atkreipti dèmesị ị būtinumą nagrinèti situacijas kartu su darbuotojais. Organizacija privalo teikti žmonèms pagalbą, ryškindama vertybinę jų orientaciją. Kai išryškinamos žmogaus vertybès, jam lengviau suprasti ir įvertinti savo poziciją tų vertybių atžvilgiu.

Darbuotojai, kurie puoselèja įmonejje dar nepripažįstamas vertybes ir principus, būdingus dvasingai organizacijai, nepaisydami daugumos nuomonès, yra priskirti ketvirtajai moralinès raidos stadijai.

Apklausos metu buvo nustatoma darbuotojų, dirbančių inovacijų komandose, moralinès raidos lygis. Čia buvo remiamasi anksčiau aprašyta keturių moralinès raidos stadijų klasifikacija. Todèl moralinès raidos stadija $(x)$ buvo vertinama nuo 1 iki 4 . Nustatyta darbuotojo atvirumo priklausomybès nuo jo moralinès raidos lygio aproksimantè:

$$
x_{1}=0,2245+0,7551 x \text {, }
$$

čia $x_{1}$ - darbuotojo atvirumas; $x$-darbuotojo moralinès raidos stadija.

Taip pat nustatyta darbuotojo idejiškumo priklausomybès nuo jo moralinès raidos lygio aproksimuojanti funkcija:

$$
x_{3}=0,7061+0,7388 x
$$

čia $x_{3}$ - darbuotojo idejiškumas; $x$-darbuotojo moralinès raidos stadija.

Tyrimai parodè, kad darbuotojo, dirbančio inovacijų komandoje, suvokimas ir jo moralinès raidos stadija nekoreliuoja.

Remiantis koreliacija nustatyta darbuotojo, dirbančio inovacijų komandoje, atvirumo ir idejiškumo priklausomybė nuo jo moralinès raidos lygio (1 lentelè). Atliktas darbuotojo kūrybingumo priklausomybès nuo jo suvokimo ir moralinès raidos lygio skaičiavimas (2 lentelè). 
1 lentelè. Darbuotojo, dirbančio inovacijų komandoje, atvirumo $\left(x_{1}\right)$ ir idejiškumo $\left(x_{3}\right)$ priklausomybè nuo jo moralinès raidos lygio $(x)$

Table 1. The dependence of opennes $\left(x_{1}\right)$ and degree of high moral quality $\left(x_{3}\right)$ on moral development level $(x)$ of an innovation team employee

\begin{tabular}{l|l|l}
\hline $\begin{array}{c}\text { Moralinès raidos } \\
\text { stadija }(x)\end{array}$ & Atvirumas $\left(x_{1}\right)$ & Idejiškumas $\left(x_{3}\right)$ \\
\hline 1 & 0,980 & 1,445 \\
\hline 2 & 1,735 & 2,184 \\
\hline 3 & 2,490 & 2,923 \\
\hline 4 & 3,245 & 3,661 \\
\hline
\end{tabular}

2 lentelè. Darbuotojo, dirbančio inovacijų komandoje, kūrybingumo $(y)$ priklausomybè nuo jo suvokimo $\left(x_{2}\right)$ ir moralinès raidos lygio $(x)$

Table 2. The team employee's creativity (y) dependence on his/ her perception $\left(x_{2}\right)$ and his/her moral development level $(x)$

\begin{tabular}{l|l|l|l|l}
\hline & $x=1$ & $x=2$ & $x=3$ & $x=4$ \\
\hline$x_{2}=1$ & 2,064 & 2,909 & 3,755 & 4,376 \\
\hline$x_{2}=2$ & 2,163 & 3,009 & 3,896 & 4,701 \\
\hline$x_{2}=3$ & 2,263 & 3,109 & 3,954 & 4,800 \\
\hline$x_{2}=4$ & 2,363 & 3,208 & 4,054 & 4,899 \\
\hline$x_{2}=5$ & 2,388 & 3,233 & 4,079 & 4,924 \\
\hline
\end{tabular}

\section{Išvados}

İvairūs veiksniai skirtingai veikia inovacijų komandos kūrybingumą. Prie neigiamai veikiančių veiksnių reikètų priskirti jos vidinès motyvacijos dirgiklius. Tai:

1. Suvaržytas pasirinkimas. Šiuo atveju komandai nustatomos ribos, kurių darbuotojai negali peržengti.

2. Priežiūra, kurią vykdo administracija, prižiūrèdama ir kontroliuodama komandos darbą.

3. Konkurencija. Administracija skatina lenktyniavimą tarp komandų ar organizacijos padalinių (lenktyniaujant problemos sprendžiamos paviršutiniškai ir mažai dèmesio skiriama esminiams klausimams).

4. Laukiamas ịvertinimas ir akcentuojamas atlygis (specialistai gali siūlyti ir bandyti naujas idejjas tik tada, kai yra saugūs dèl darbo vietos ir atlygio. Jų pastangos turètų būti deramai atlygintos pastoviu darbo užmokesčiu ir tuo atveju, jei darbas nebuvo rezultatyvus).

Inovacijų komandoje gali kilti problemų dèl jos narių suderinamumo profesinès kompetencijos srityje. Tačiau daugiausia problemų kyla dèl komandos narių asmeninio suderinamumo. Komandai pereinant ịvairias formavimosi stadijas, kyla jos narių tarpusavio priklausomybès, atsakomybès, atvirumo, pasitikejimo problemos. Efektyviai dirbantys vadovai jaučia, kada komandai reikalinga visa ar iš dalies apribota laisve ir kada reikalinga organizacijos pagalba. Inovacijų komandos kūrybingumą veikia ne tik organizaciniai veiksniai, bet ir jos narių asmeninès savybès: suvokimas, atvirumas ir idejjiškumas.
Atliktas darbuotojų, dirbančių inovacijų komandose, kūrybingumo veiksnių: atvirumo, suvokimo ir idejiškumo - tyrimas parodè, kad didžiausią ittaką kūrybingumui turi darbuotojo idejjiškumas, kuris atspindi asmenybès siekị tobulèti. Reikšmingą įtaką turi ir atvirumas, atspindintis asmenybès gebẻjimą kvestionuoti susiformavusias pažiūras. Mažiausiai reikšmingas kūrybingumo veiksnys - suvokimas, atspindintis asmenybès siekị pažinti.

İvairių darbuotojų i̇sipareigojimo organizacijai lygis nèra vienodas. Jų sprendimų prièmimą ir elgesį organizacijoje nevienodai veikia baimès jausmas ir asmeniniai interesai. Atsižvelgdami įvertybinę darbuotojų orientaciją, galime ne tik sistemingai nagrinèti inovacijų komandos narių siekị pažinti, gebejimą kvestionuoti savo pažiūras, siekį tobulèti, bet ir geriau suprasti, kodèl skirtingi žmonès savo sprendimams taiko skirtingus etinius standartus. Tai priklauso nuo jų moralinès raidos lygio. Straipsnyje pateikta siūloma moralinès raidos lygio loginès gradacijos schema, kurią sudaro keturios moralinės raidos stadijos. Pirmajai stadijai siūloma priskirti darbuotojus, kurių sprendimus riboja baimès jausmas, silpninantis žmogaus valią, gniuždantis iniciatyvą, veiklumą ir kūrybingumą. Antrajai stadijai siūloma priskirti darbuotojus, kurių sprendimus riboja asmeniniai interesai. Trečiajai stadijai priskirtini darbuotojai, kurie, priimdami sprendimus, laikosi ịsipareigojimų organizacijai principo. Tokie darbuotojai, priimdami sprendimus ir vykdydami prisiimtus įsipareigojimus, laikosi nustatytos organizacijoje tvarkos. Darbuotojus, kurie puoselèja įmonèje dar nepripažĭstamas vertybes ir principus, būdingus dvasingai organizacijai, nepaisydami daugumos nuomonès, siūloma priskirti ketvirtajai moralinès raidos stadijai.

Atliktas tyrimas taikant ekonometrinius metodus, parodè, kad darbuotojo, dirbančio inovacijų komandoje, moralinès raidos lygis turi ịtakos jo atvirumui, atspindinčiam gebejjimą kvestionuoti savo pažiūras, ir idejiškumui, atspindinčiam tobulumo siekį. Darbuotojo suvokimas, atspindintis pažinimo sieki, nekoreliavo su jo moralinès raidos stadija.

Darbuotojo, dirbančio inovacijų komandoje, kaip asmenybės kūrybingumui tirti siūlomas modelis, jungiantis šiuos veiksnius: idejiš̌kumą ir atvirumą, kurie priklauso nuo jo moralinès raidos lygio, ir suvokimą. Asmenybès moralinès raidos stadiją, remiantis jo elgesiu, turètų nustatyti bendradarbiai. Idejiškumas, suvokimas ir atvirumas vertinami balais apklausos metu. Juos turètų nustatyti tiriamojo bendradarbiai. Žinant darbuotojų moralinès raidos lygio charakteristikas ir jų įtaką tobulumo siekiui bei gebejimui kvestionuoti susiformavusias pažiūras, galima tikslingiau formuoti inovacijų komandas. Natūralu, kad komandoje susidaro įvairių lygių mišinys. Svarbu, kokio lygio yra dauguma ir kokị statusą bei vaidmenị komandoje užims aukštesnès moralinès raidos lygio nariai. Nuo to priklauso ne tik kokiais kriterijais remsis komandos nariai, priimdami sprendimus profesinès kompetencijos srityje, bet ir kaip bendraus, kokios normos susiformuos. 


\section{Literatūra}

Ashmos, D. P.; Duchon, D. 2000. Spirituality at work: a conceptualization and measure, Journal of Management Inquiry June, 139.

Becker, T. E.; Billings, R. S.; Eveleth, D. M.; Gilbert, N. L. 1996. Foci and bases of employee commitment: implications for job performance, Academy of Management Journal 39: 464-482. http://dx.doi.org/10.2307/256788

Conlin, M. 1999. Religion in workplace: the growing presence of spirituality in corporate America, Business Week November 1: 151-158.

Elizur, D.; Koslowsky, M. 2001. Values and organizational commitment, International Journal of Manpower 22: 593-599. http://dx.doi.org/10.1108/01437720110408967

Frankl, V. E. 2007. Sielogyda. Vilnius: Vaga. 354 p.

Goleman, D. 2007. Emocinis intelektas. Vilnius: Presvika. 361 p.

Kasiulis, J.; Barvydiene, V. 2005. Vadovavimo psichologija. Kaunas: Technologija. 327 p.

Kavaliauskienè, Ž. 2009. Organizacinis ịsipareigojimas kaip teorinis konstruktas, Ekonomika ir vadyba: aktualijos ir perspektyvos 2(15): 82-93.

Maceika, A.; Strazdas, R.; Maciukevičienè, L. 2007. Darbuotojų inovatyvumas pramonès įmonių vertybių sistemoje, Verslas: teorija ir praktika [Business: Theory and Practice] 8(1): 44-50. http://dx.doi.org/10.3846/btp.2007.08

McCormik, D. W. 1994. Spirituality and management, Journal of Managerial Psychology 9(6): 5-9. http://dx.doi.org/10.1108/02683949410070142

Meyer, J. P.; Stanley, D. J.; Herscovitch, L.; Topolnytsky, L. 2002. Affective, continuance and normative commitment to the organization: a meta - analysis of antecedents, correlates and consequences, Journal of Vocational Behavior 61(3): 20-52. http://dx.doi.org/10.1006/jvbe.2001.1842
Mirvis, P. H. 1997. Soul work in organizations, Organization Science 8(2): 193-197. http://dx.doi.org/10.1287/orsc.8.2.192

Petkevičiūtè, N.; Kalnina, I. 2004. Veiksniai, didinantys darbuotojų organizacinị ịsipareigojimą, Organizacijų vadyba: sisteminiai tyrimai 31: 179-193.

Riketta, M. 2005. Organizational identification: a meta - analysis, Journal of Vocational Behavior 66: 358-384. http://dx.doi.org/10.1016/j.jvb.2004.05.005

Robbins, S. P. 2003. Organizacinés elgsenos pagrindai. Kaunas: Poligrafija ir informatika. $374 \mathrm{p}$.

Rogers, C. R. 2005. Apie tapima asmeniu. Vilnius: Via Recta. $187 \mathrm{p}$.

Runco, M. A. 2004. Creativity, Annual Reviews of Psychology 55: 657-687. http://dx.doi.org/10.1146/annurev.psych.55.090902.141502

Simonton, D. K. 2000. Creativity: cognitive, personal, develomental and social aspects, American Psychologist 55-1: 151-158.

Tatarkiewicz, W. 2007. Šešių sąvokų istorija. Vilnius: Vaga. 488 p.

Urban, K. K. 1990. Recent trends in creativity research and theory in Western Europe, European Journal for High Ability 1: 99-113. http://dx.doi.org/10.1080/0937445900010114

Van Vianen, A. E. M. 2000. Person-organization fit: the match between "newcomers" and "recruiters" preferences for organizational cultures, Personnel Psychology 63: 1-32.

Vuuren, M.; Veldkamp, B. P.; Jong, M. D. T.; Seydel, E. R. 2008. Why work? Aligning foci and dimensions of commiment along the axes of the competing values framework, Personnel Review 37(1): 47-65. http://dx.doi.org/10.1108/00483480810839969

Wagner-Marsh, F.; Conley, J. 1999. The spirituality - based firm, Journal of Organizational Change Management 12(3): 292-302. http://dx.doi.org/10.1108/09534819910282135

Irena ZABIELAVIČIENĖ. Doctor of Social Sciences, Associate Professor, Department of Industrial Enterprises Management, Vilnius Gediminas Technical University. Research interests: management accounting, decision making, innovation, organizational behaviour. 